\title{
Tumor Necrosis Factor Ligand Superfamily Member 18
}

National Cancer Institute

\section{Source}

National Cancer Institute. Tumor Necrosis Factor Ligand Superfamily Member 18. NCI

Thesaurus. Code C142776.

Tumor necrosis factor lig and superfamily member 18 (199 aa, $23 \mathrm{kDa}$ ) is encoded by the human TNFSF18 gene. This protein plays a role in the positive regulation of both activation and proliferation of T-cells. 